\title{
Oil, Nontax Revenue, and the Redistributional Foundations of Regime Stability
}

\author{
Kevin M. Morrison
}

\begin{abstract}
Nontax revenues make up a substantial amount of government revenue around the world, though scholars usually focus on individual sources of such revenue (for example, foreign aid and state-owned oil companies). Using a theory of regime change that builds on recent models of the redistributional foundations of dictatorships and democracies, I generate hypotheses regarding all nontax revenue and regime stability. I argue that an increase in nontax revenue should be associated with less taxation of elites in democracies, more social spending in dictatorships, and more stability for both regime types. I find support for all three of these hypotheses in a cross-sectional time-series analysis, covering all countries and years for which the necessary data are available. Significantly, I show that the particular source of nontax revenue does not make a difference: they all act similarly with regard to regime stability and the causal mechanisms.
\end{abstract}

Given the prominence of oil in international affairs, it is not surprising that scholars have generated a considerable amount of research about its effects on politics. Perhaps more surprising is the general conclusion that much of this literature reaches. One of oil's most important effects seems to be the simple fact that it

I am grateful for excellent research assistance from Dylan Fagan; for comments and encouragement from Despina Alexiadou, Carles Boix, David Brady, Tim Büthe, David Davis, John Doces, Oeindrila Dube, James Galbraith, Clark Gibson, Joyee Ghosh, Marcela González Rivas, Torben Iversen, Seth Jolly, Anton Korinek, Dan Kselman, Stephan Litschig, Akbar Noman, Brendan Nyhan, Michael Ross, Alberto Simpser, Matt Singer, Dan Slater, Joseph Stiglitz, Camber Warren, Steven Wilkinson, anonymous reviewers, and the editors of International Organization; and especially for suggestions and guidance from Karen Remmer and Robert Keohane. I am also indebted to participants at meetings and workshops where versions of this article were presented, including the Advanced Graduate Workshop on Poverty, Development, and Globalization at the University of Manchester (UK); the Annual Meeting of the American Political Science Association; the Harvard University Comparative Political Economy Workshop; and seminars at Cornell University, Duke University, Emory University, Ohio State University, Pennsylvania State University, Princeton University, the University of California at Irvine, the University of Chicago, and the University of Texas at Austin. All errors are mine. Finally, I gratefully acknowledge the financial support of a post-doctoral fellowship at Princeton University's Niehaus Center for Globalization and Governance, a National Science Foundation (NSF) Graduate Research Fellowship, a James B. Duke Fellowship, and a Vertical Integration Grant from the Duke University Graduate School. Any opinions, findings, conclusions, or recommendations expressed in this article are those of the author and do not necessarily reflect the views of the NSF or any entity of Duke, Princeton, or Cornell.

International Organization 63, Winter 2009, pp. 107-38

(C) 2009 by The IO Foundation.

doi:10.1017/S0020818309090043 
gives political regimes more money with which to pursue their various strategies for staying in power. ${ }^{1}$ As Jensen and Wantchekon state, "The key mechanism linking authoritarian rule and resource dependence, both in democratic transition and democratic consolidation, is an incumbent's discretion over the distribution of natural resource rents." 2 Similarly, Smith notes, "While scholars approach the political economy of oil from diverse methodological origins, the theoretical arguments about the structures and nature of the rentier state flow from the state's access to externally obtained revenues from the sale of oil." ${ }^{3}$ By this argument, the ways in which governments use oil revenue are just a reflection of their preferences over the use of state finances. ${ }^{4}$

This way of thinking about the relationship between oil wealth and political regimes raises an important question: if it is revenue doing the work, why is oil revenue different from other kinds of revenue, particularly others that are also "externally obtained"? In fact, there may be a variety of such revenues, whose key characteristic is that they are not derived from taxation but rather available mainly as "windfalls" to the government. Along these lines, several scholars have suggested that the literature on oil revenues may have relevance for another fungible, external resource: foreign aid. ${ }^{5}$ The implication is that oil revenues may not be particularly unique, except for the fact that they make up a large percentage of such externally obtained revenues.

While a revenue perspective reveals certain similarities between foreign aid and oil rents, it should be noted that conventional wisdom about these two revenue sources often seems to imply opposite predictions about their effects on political regimes. This wisdom is reflected in the contrasting titles of two important recent studies: while Ross asks "Does Oil Hinder Democracy?", Knack asks "Does Foreign Aid Promote Democracy?" 6 Despite the efforts of some scholars discussed below, the prevailing assumption is that oil generally has negative (that is, anti-

1. Though this is a central message of research on the "rentier" state, the particular arguments developed within this literature vary, as do governments' strategies for staying in power, which range from "buying" political consensus to repressing various social groups. See, for example, Anderson 1995; Chaudhry 1997; Goldberg, Wibbels, and Mvukiyehe 2008; Karl 1997; Moore 1976; and Shambayati 1994. In addition, there are subtle differences in the hypothesized effects of oil revenues. Some (see, for example, Ross 2001; and Ulfelder 2007) argue that oil bolsters authoritarianism, whereas others (for example, Smith 2004) suggest that it stabilizes all regimes.

2. Jensen and Wantchekon 2004.

3. Smith 2004, 233.

4. It should be noted that while the rentier hypothesis, revolving around revenue, is the dominant strand in the oil literature, there are some hypotheses relating oil to political regimes that do not revolve around revenue. For example, oil's dominance of the economy may lead to less emphasis on education and less urbanization, thereby breaking a possible "modernization" link between economic development and democratization (Ross 1999).

5. See, for example, Bräutigam 2000; Moore 1998; Smith 2008; and Therkildsen 2002. It is interesting to note in this context that Hussein Mahdavy's $(1970,428)$ original definition of a rentier state was a state that received substantial rents from "foreign individuals, concerns or governments" (also see Herb 2005).

6. See Knack 2004; and Ross 2001. 
democratic) implications for political regimes, while aid has positive ones. What would it mean if aid and oil were to have similar political properties? Should rich countries interested in democracy avoid giving foreign aid to poor countries?

This article argues that foreign aid and the majority of oil revenues do indeed have similar effects, because they are examples of nontax revenue, a class of revenue that has not received much scholarly attention despite its prevalence throughout the world. However, these revenues do not have "antidemocratic" properties, or even "prodemocratic" properties. What they have are stabilizing properties, in the sense that their presence reduces the probability of a regime transition in both democracies and dictatorships. These revenues enable a regime to stay in power by whatever means are best for that regime, and this is as true in democracies as it is in dictatorships. This different way of thinking about revenue has particular implications for policy, and it suggests that the recent rise in - and increasing diversity of - nontax revenue may lead to a period of greater stability in both the developing world and the international system. I will return to these implications at the end of the article.

To explore the impact of these revenues, I first review the relevant literature on revenue and regime stability, and then develop a theoretical framework based on a distinguished body of work that has related political regime changes to redistributional pressures in society. Using this framework, I generate hypotheses not only about the stabilizing effects of nontax revenues, but also about the causal mechanisms through which they might work. I then discuss the data on nontax revenue and provide descriptive statistics on its prevalence, showing that this revenue makes up about a quarter of government revenue around the world. Finally I analyze the 1973-2001 period and demonstrate that nontax revenue led to more regime stability in all countries, whether they were democracies or dictatorships. I also provide evidence in support of certain causal mechanisms suggested by my theoretical approach: nontax revenue is associated with increased social spending in dictatorships and less taxation of elites in democracies. Significantly, this article shows that the particular source of nontax revenue-state-owned enterprises, aid, or other sources-does not make a difference: they all act similarly with regard to regime stability and the causal mechanisms.

\section{Theoretical Perspectives on Regime Change and Stability}

An important body of work has arisen from the emphasis placed on the importance of revenue for the nature of regimes in landmark works by Schumpeter, Musgrave, Brennan and Buchanan, and Levi. ${ }^{7}$ For the purposes here, the existing research is usefully divided into that focused on tax revenue and that focused on

7. See Brennan and Buchanan 1980; Levi 1988; Musgrave 1959; and Schumpeter 1991. 
nontax revenue (there is no work I know of that addresses them both within a theoretical framework). ${ }^{8}$

The literature on tax revenue and regime stability has typically concentrated on the hypothesized linkage between taxation and representation in the transition from autocracies to democracies. The principal argument is that important Western democracies arose as a result of a bargain: rulers in need of resources were forced to grant representation in exchange for taxes. ${ }^{9}$ As Ross points out, there are two different versions of this argument. ${ }^{10}$ One, seemingly supported by scholars such as Brennan and Buchanan and Huntington, is that citizens demand representation in exchange for higher levels of taxes. ${ }^{11}$ The other argument, seemingly supported by the likes of Bates and Lien, is more conditional: citizens demand representation if the ratio of government services to taxes falls below a certain threshold. ${ }^{12}$ Ross provides cross-national statistical tests for these theses, finding support for the latter but not the former. ${ }^{13}$

There is no work I know of that focuses on nontax revenue, as such, and its relation to regime stability. However, particular kinds of nontax revenue have been studied on their own. Revenues from oil-the presence of which was shown by Smith to increase regime stability ${ }^{14}$ — can be considered an example of nontax revenue. The majority of government revenue generated from oil comes not through taxes (such as on foreign companies) but rather through state-owned companies, which control an estimated 75 percent of the world's oil production and 90 percent of its reserves. ${ }^{15}$ Ross and Luong and Weinthal have suggested that this state ownership of oil companies may be a factor in the association of oil wealth with poor economic performance. ${ }^{16}$ More importantly for the purposes at hand, state ownership of oil companies may also be important for the association of oil wealth with regime stability.

Another kind of nontax revenue that has been studied on its own is foreign aid. Research has indicated that foreign aid is a highly fungible resource ${ }^{17}$ and acts similarly to oil in that it provides extra resources the government can use to dis-

8. It should be noted that this article focuses on regime stability in the sense of authoritarian regimes switching to democratic ones, and vice versa. The literature on this topic has existed parallel to a literature on regime stability in the sense of political regimes succumbing to civil war. For a recent work that examines revenue in the context of this latter kind of regime stability, see Snyder and Bhavnani 2005. Ideally, these literatures would coincide-theoretically and empirically — more than they do now.

9. See Bates and Lien 1985; Levi 1988; North and Weingast 1989; and Tilly 1990.

10. Ross 2004.

11. See Brennan and Buchanan 1980; and Huntington 1991.

12. Bates and Lien 1985.

13. Ross 2004.

14. Smith 2004.

15. Ivanhoe 2000

16. See Luong and Weinthal 2006; and Ross 1999.

17. Feyzioglu, Swaroop, and Zhu 1998. 
tribute to its key constituencies without taxation. ${ }^{18}$ For example, van de Walle has argued that democratization in Africa was encouraged by a fiscal crisis resulting from, among other things, an increased willingness on the part of donors to restrict aid to countries that did not respect human rights: "With fewer resources at their disposal and an increasingly decrepit state apparatus, leaders found it harder to sustain critical clientelist networks, with the result that the old political aristocracy was more likely to fractionalize." ${ }^{19}$ To my knowledge, no one has directly tested statistically whether aid leads to increased regime stability. ${ }^{20}$

There are, then, several different revenue sources that one might consider to be important for regime stability. However, no theory currently exists that could help explain how these different kinds of revenue affect one another and interact to affect regime stability. A potentially productive way to start constructing such a theory - and the way in which hypotheses will be generated for this study-is to build on works that focus on redistributional conflicts as central to regime change. This approach to regime change has a distinguished history, including the landmark analyses of Moore and Rueschemeyer, Stephens, and Stephens. ${ }^{21}$ Because the more recent contributions of Boix and Acemoglu and Robinson have specifically modeled the ways in which government revenue interacts with demands from society in the context of political regime transitions, they provide a useful framework on which to build. ${ }^{22}$

In order to understand the background of the hypotheses generated in this study, it is necessary to recognize five defining aspects of these theories. First, these theories assume that political regimes are essentially a way of allocating resources in society. ${ }^{23}$ As such —almost by definition—conflict over the political regime is conflict about the nature and extent of redistribution in society. Second, these theories tend to assume that conflict over redistribution takes place between citizens and wealthy elites. ${ }^{24}$ Third, they assume that the elites in society are a smaller group than the citizens. This characteristic is important because it leads to the association of dictatorial regimes with elites and democratic regimes with citizens. Dictatorial regimes are ones in which a minority group — the wealthy elites in societyhave decision-making power over resource allocation. Democratic regimes are ones in which the citizens have that power.

18. For example, Bratton and van de Walle 1997.

19. van de Walle 2001, 240.

20. There have been some works analyzing statistically the effect of aid on a country's level of democracy. Goldsmith 2001 and Dunning 2004 find a small but significant positive correlation between level of democracy in Africa and aid as a percentage of GNP, but Knack 2004 finds no correlation between improvements in level of democracy and aid as a percentage of either GNP or government spending.

21. See Moore 1966; and Rueschemeyer, Stephens, and Stephens 1992. Also see Therborn 1977.

22. See Acemoglu and Robinson 2001 and 2006; and Boix 2003.

23. Kitschelt 1992.

24. It may be noted that the central theoretical claims of the work by Acemoglu and Robinson are robust to the presence of other societal divisions (such as ethnic divisions), but it is important for their model that there are elites and citizens within these societal groups (see, for example, Acemoglu and Robinson 2006, 203-7). 
The key implication is that transitions to democracy should generally involve (1) an incorporation of poorer elements into the country's electorate and (2) an improvement in the government's treatment of those parts of society. Although there are certainly exceptions, this is a plausible way of viewing the history of enfranchisement, which has generally been one of widening the electorate to include poorer groups in the "social hierarchy." 25 Furthermore, as these theories would predict, the expansion of the franchise has resulted in important policy changes. Lindert, for example, has carefully documented how the extension of suffrage rights to poorer social groups in Western countries at the end of the nineteenth and beginning of the twentieth centuries led to an expansion of both social insurance and public education provision. ${ }^{26}$ Bueno de Mesquita and his co-authors have also provided support for this approach, showing that as the size of the winning coalition in a regime increases, so do important education and health indicators. ${ }^{27}$

The fourth important characteristic of these theories of regime change and stability is that, in their focus on redistribution, they have ignored the possibility of a "distributive" state. ${ }^{28}$ In particular, the models of Boix ${ }^{29}$ and Acemoglu and Robinson ${ }^{30}$ build off the benchmark model of redistribution by Meltzer and Richard. ${ }^{31}$ The state has no resources of its own, but rather redistributes - through taxationresources owned by the societal groups. Largely ignored is the possibility that the state might have resources of its own: nontax revenues.

Finally, the fifth characteristic is that redistribution is generally considered to be transfers from elites to citizens, and not the other way around..$^{32}$ It is a rather quick jump from this characteristic to the critical source of conflict in these models: citizens prefer higher redistribution than elites. In fact, elites prefer no redistribution at all.

Together, these characteristics lead to specific predictions about the source of threats to democracies and dictatorships. For dictatorships, the threat is from citizens, who are unhappy about the amount of transfers they are receiving. In the Acemoglu and Robinson theory, for example, dictatorships fall during transitory moments when citizens have solved their collective action problem and can mobilize against the elites. ${ }^{33}$ If the elites cannot credibly promise enough transfers to keep citizens from launching a revolution, elites democratize, thereby putting allo-

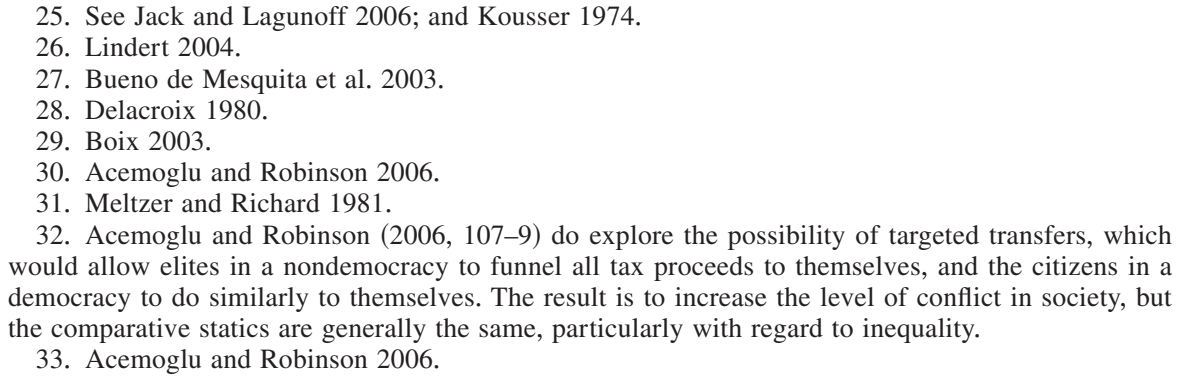

32. Acemoglu and Robinson (2006, 107-9) do explore the possibility of targeted transfers, which would allow elites in a nondemocracy to funnel all tax proceeds to themselves, and the citizens in a democracy to do similarly to themselves. The result is to increase the level of conflict in society, but the comparative statics are generally the same, particularly with regard to inequality.

33. Acemoglu and Robinson 2006. 
cation decisions in the hands of the citizens. For democracies, the threat is exactly from those elites, who are now unhappy with the level of taxation and can threaten a coup. In the transitory moments when the rich solve their own collective action problem and mobilize against the regime, citizens may not be able to credibly promise lower amounts of taxation of elites. In this scenario, the rich overthrow the democracy and impose a dictatorship.

As mentioned above, however, theories within this framework have assumed that government revenue only comes from taxation. What happens in these theories when there is nontax revenue available to the different political regimes? In a recent article,$^{34}$ I have used a model similar to that of Boix and Acemoglu and Robinson to show that nontax revenue should lead to greater regime stability in dictatorships (preventing democratization). The causal mechanism is that this revenue provides the regime with a greater ability to appease citizens (the threat to the regime in this framework), and thereby prevent a revolution or transition to democracy. In democracies, the causal mechanism is different, since the threat to the regime is instead from the elites. Using a similar model in an appendix to this article available on my Web site, I present a proof that nontax revenue should lower the preferred tax rate of citizens in democracies. ${ }^{35}$ If there are diminishing marginal returns to government spending, the presence of nontax revenue will reduce the desire of citizens to raise tax revenue. ${ }^{36}$ With a lower tax burden, elites have less dissatisfaction with democracy. The result is that nontax revenue should lead to increased regime stability in democracies.

The theoretical approach advanced in this study therefore leads to three testable hypotheses. The first concerns the end result: the presence of nontax revenue should be associated with greater regime stability in both democracies and dictatorships. The second and third hypotheses concern the causal mechanisms: nontax revenue should lead to certain changes in the finances of democracies and dictatorships. In democracies, nontax revenue should be associated with less taxation of richer elites. In dictatorships, nontax revenue should be associated with increased spending on poorer citizens. The empirical sections of this article explore these three hypotheses, first examining the relationship between nontax revenue and regime stability and then establishing that the causal mechanisms hold.

\section{Nontax Revenue around the World}

As the conception of nontax revenue advanced above is relatively new, it is useful to begin with a discussion of the extent to which such revenue is an important

34. Morrison 2007.

35. See $\langle$ http://falcon.arts.cornell.edu/kmm368/〉. Dunning 2008 has developed a similar model specifically focusing on oil rents.

36. Such diminishing returns are usually assumed to come from distortions that high levels of government spending can create in the economy. See Alesina et al. 2002; and Landau 1985. 
source of finance for countries around the world. The best available data on revenue is from the International Monetary Fund (IMF) publication Government Finance Statistics (GFS). Unfortunately for researchers interested in revenue over a long time period, the IMF recently changed the way it categorizes government finance. ${ }^{37}$ However, the data for the previous coding by the IMF is available over a time period of $1973-2001 .^{38}$ Therefore, to attain a longer time-series, I have used the previous coding of revenue and spending.

In my theory, nontax revenue includes not only foreign aid and natural resource revenue attained through state-owned enterprises, but also borrowing (from abroad or the Central Bank) and all other revenue besides taxation (for example, other state-owned enterprise revenue, fines, and so forth). ${ }^{39}$ Essentially, nontax revenue is what the government can spend without having to tax its citizens. This is obviously quite a diverse category of revenue, and it should be noted at the outset that-despite scholars' claims that aid and oil revenues might have something in common-asserting that they can be aggregated into one category constitutes a hypothesis in its own right. Therefore I will take steps below in my empirical analysis to ensure that this hypothesis is valid.

However, if aggregating seemingly different forms of revenue into one category seems counter-intuitive at first, consider that research on taxation and political regimes has primarily focused on aggregate taxation, despite the evident differences that exist between various forms of taxes. ${ }^{40}$ Much insight, similarly, has been gained by focusing on aggregate government spending, discounting differences between various kinds of expenditure. ${ }^{41}$ Research on nontax revenue to date (though not positioned as such) has instead focused primarily on disaggregated types of revenue, such as oil revenues or foreign aid. As in works that have focused on aggregate taxation and spending, this article will offer evidence that leverage on understanding certain phenomena can be gained by aggregating different kinds of nontax revenue. Furthermore, unlike the large majority of works focusing on aggregate taxation and spending, I will demonstrate that disaggregated forms of nontax revenue do in fact have similar effects.

Given the encompassing theoretical definition of nontax revenue, the simplest way of calculating the aggregate value of such revenue is to subtract total tax revenue from total expenditures. This gives a direct measure of the revenue other than tax revenue that the government can use to finance expenditures. Nontax revenue defined in this way is available for 2,055 observations from 118 countries, and the variable exhibits variance both cross-sectionally (a "between" standard deviation of 689 constant \$US per capita) and across time (a "within" standard deviation of $\$ 582$ per capita). Analyzing the related descriptive statistics reveals

37. International Monetary Fund 2001.

38. The previous coding is detailed in International Monetary Fund 1986.

39. This can be seen in the equations in Morrison 2007.

40. See, for example, Cheibub 1998; and Ross 2004.

41. See, for example, Rodden 2003; and Rodrik 1998. 
that this kind of revenue is critical to many countries in the world. It accounts for an average of 27 percent of government expenditures in the sample, and in some countries it accounts for the large majority of expenditures, as Table 1 details.

TABLE 1. The importance of nontax revenue in some countries' revenue streams (percentage of total expenditures covered by nontax revenue)

\begin{tabular}{|c|c|c|c|c|}
\hline & Mean & $\begin{array}{l}\text { Standard } \\
\text { deviation }\end{array}$ & Minimum & Maximum \\
\hline Bahrain & 77 & 5 & 68 & 84 \\
\hline Bhutan & 84 & 2 & 80 & 87 \\
\hline Bolivia & 42 & 10 & 26 & 56 \\
\hline Burundi & 44 & 6 & 34 & 56 \\
\hline Congo, Rep. & 59 & 17 & 31 & 82 \\
\hline Egypt & 44 & 6 & 35 & 61 \\
\hline Ethiopia & 46 & 7 & 34 & 56 \\
\hline Greece & 32 & 11 & 16 & 51 \\
\hline Iran & 67 & 12 & 38 & 86 \\
\hline Israel & 34 & 8 & 24 & 56 \\
\hline Japan & 28 & 12 & 3 & 44 \\
\hline Mali & 46 & 18 & 17 & 62 \\
\hline Nepal & 54 & 7 & 43 & 65 \\
\hline Nicaragua & 35 & 14 & 0 & 59 \\
\hline Pakistan & 38 & 7 & 24 & 48 \\
\hline Romania & 47 & 30 & 6 & 77 \\
\hline Syria & 50 & 22 & 16 & 78 \\
\hline
\end{tabular}

Notes: Calculated using data from the IMF's Government Finance Statistics. Figures are for observations in my sample covering 1973-2001. 100 $=100$ percent.

As further evidence of their importance, these nontax revenues are also large relative to the size of the economy. Table 2 lists some major components of revenue as a share of gross domestic product (GDP) by region, as well as the specific definitions of these variables used in the statistical analysis below. Included are tax revenue and two of the major components of nontax revenue: foreign aid receipts and an approximation of income from state-owned enterprises. This latter variable includes income from state-owned oil companies. The table also lists the regional averages of oil exports as a share of GDP, a common indicator of oil dependence. ${ }^{42}$ Comparing these various indicators serves notice that the geographical extension of a theory of nontax revenue is likely to be different than a theory

42. See Ross 2001; and Smith 2004. 
focused on oil or aid exclusively. For example, while many oil revenues will be included in my nontax revenue variable, the correlation between my nontax revenue variable and oil exports as a share of GDP is only 0.18. While the Middle East is ranked first in terms of both nontax revenue and oil, its oil/GDP ratio is almost three times that of the next highest region, and twenty times that of the lowest-ranked region. In contrast, the Middle East's nontax revenue/GDP ratio is only about 1.5 times that of the next highest region, and only about four times that of the lowest-ranked region. Similar comparisons can be made between the geographical extensions of theories of nontax revenue and theories of foreign aid. The tables accordingly underline the importance of nontax revenue to governments around the world, highlighting the need to understand the political impact of this kind of revenue.

TABLE 2. The importance of nontax revenue, in economic terms (variables as a percentage of $G D P$ )

\begin{tabular}{lccccc}
\hline & $\begin{array}{c}\text { Oil } \\
\text { exports }\end{array}$ & $\begin{array}{c}\text { Tax } \\
\text { revenues }\end{array}$ & $\begin{array}{c}\text { State-owned } \\
\text { enterprise } \\
\text { revenue }\end{array}$ & $\begin{array}{c}\text { Foreign } \\
\text { aid }\end{array}$ & $\begin{array}{c}\text { Total } \\
\text { nontax } \\
\text { revenues }\end{array}$ \\
\hline Middle East and North Africa & 20 & 17 & 15 & 3 & 20 \\
South Asia & 1 & 12 & 5 & 4 & 13 \\
Sub-Saharan Africa & 4 & 18 & 3 & 2 & 9 \\
Europe and Central Asia & 2 & 29 & 4 & 1 & 7 \\
Latin America and Caribbean & 4 & 18 & 3 & 1 & 6 \\
East Asia and Pacific & 4 & 16 & 3 & 1 & 5 \\
\end{tabular}

Notes: Regional breakdowns are as defined by the World Bank. Oil exports as a share of GDP are from the World Bank. "Tax revenues," as defined by the IMF's (1986) Government Finance Statistics (GFS), are "compulsory, unrequited payments to government" (p. 118). "State-owned enterprise revenue" is approximated here by the variable NONTAX REVENUE in the GFS. While this category also includes administrative fees and charges, the majority of this revenue is the government's "entrepreneurial and property income." "Foreign aid" is the GRANTS variable in the GFS and includes "all nonrepayable unrequited payments received from other governments or programs, for general budget support, or any other purpose" (p. 130). "Total nontax revenues" are as defined in the text. $100=100$ percent.

\section{Analysis of the Regime Change Hypothesis}

I begin the statistical analysis by establishing that my first hypothesis holds: nontax revenue should be associated with greater regime stability. To assess this hypothesis, I draw on a binary dependent variable (REGIME INSTABILITY) that takes a value of 1 if there is a regime change from one year to the next, and 0 otherwise. Similar to Smith in his study of regime instability, ${ }^{43}$ a regime is considered to have changed if it receives a 0 in Polity IV's DURABLE variable, which counts the

43. Smith 2004. 
number of years since the most recent regime change. ${ }^{44}$ A regime change in Polity IV is defined by a change of three points or more in the POLITY variable-which ranges from -10 (most authoritarian) to 10 (most democratic) —or the end of a transition period. By this definition, there are transitions in about 5 percent of the observations reported below.

The key independent variable in the model is NONTAX REVENUE PER CAPITA. ${ }^{45}$ It is calculated, using the IMF's GFS, by subtracting tax revenue from total expenditures (both in constant 1995 US dollars) and dividing by total population as reported in the World Bank's World Development Indicators. It should be noted that if different kinds of nontax revenue had different effects on regime stability, it would be difficult to find a significant result for this variable (for example, variables with both negative and positive effects would be aggregated into one variable). However, to be sure that combining them into one indicator is justifiable, I begin my analyses by including various components of nontax revenue separately in the regressions, as I will discuss shortly.

A simple logit regression of the regime instability dependent variable on nontax revenue yields a negative and significant coefficient (indicating that nontax revenue has a stabilizing effect), with a p-value of .024. However, it is important to control for other variables that might also be affecting regime stability, to ensure confidence in the results regarding nontax revenue. I therefore generally use the same control variables as Smith. ${ }^{46}$ First, I control for ETHNOLINGUistic FRACTIONALIZATION, since some scholars have argued that social fragmentation increases regime instability. ${ }^{47}$ The measure I use is the probability that two randomly chosen individuals in a country do not speak the same language. Roeder's data set provides observations of this variable for both 1961 and $1985 .{ }^{48}$ For all observations prior to and in 1980, I use the 1961 measure, and for all subsequent years I use the 1985 measure. Second, I control for the natural log level of, and growth in, GDP PER CAPITA, following many scholars who have shown a relationship between these indicators and regime stability. ${ }^{49}$ Third, I control for the change in the percentage of the population that is urban ( $\Delta \%$ POPULATION URBAN), since some scholars have found that urbanization can be destabilizing for regimes. ${ }^{50}$ Fourth, I include the level of POPULATION DENSITY, to control for the possibility of a relationship between population, land, and regime stability. ${ }^{51}$ These last three variables come from the World Bank. ${ }^{52}$

44. Marshall and Jaggers 2003.

45. The standardization by population is suggested directly by the formal models in Morrison 2007. It captures the intuition that a given amount of revenue is less useful to regimes if it needs to be distributed among more people.

46. Smith 2004.

47. For example, Horowitz 1985.

48. Roeder 2001.

49. See, for example, Lipset 1959; Przeworski et al. 2000; and Remmer 1991.

50. See, for example, Huntington 1968.

51. See Fearon and Laitin 2003; and Herbst 2000.

52. World Bank 2004. 
The estimation technique used is logistic analysis with errors clustered by country. However, as Beck and his co-authors have detailed, cross-sectional timeseries data with a binary dependent variable are likely to violate the independence assumption of ordinary logistic analysis. ${ }^{53}$ Therefore, as recommended by Beck and his co-authors and implemented by others, ${ }^{54}$ I control for PAST REGIME INSTABILITY in a country, measured as the number of all past regime changes in that country in the sample. In addition, following Beck and his co-authors, I included cubic splines of the political REGIME AGE in a given year, to capture temporal dependence in the data. ${ }^{55} \mathrm{~F}$-tests revealed that these splines were necessary to include in the regressions. As Beck and his co-authors detail, including these splines makes logistic analysis identical to survival analysis techniques.

Table 3 reports the results. I first make sure that combining the nontax revenue categories into one variable is justified. Model 1 reports the results of the regression with three categories of nontax revenue entered separately. These components are foreign aid (GRANTS PER CAPITA), an indicator of state-owned enterprise revenue (SOE REV. PER CAPITA), and a residual indicator consisting of the aggregate nontax revenue variable minus these two components (OTHER NONTAX REV. PER CAPITA). An important part of this third category is borrowing, to finance deficit spending for example (definitions for each indicator are presented below Table 2). ${ }^{56}$ These disaggregated components are available for a smaller set of observations than the aggregate nontax revenue variable, which is calculated using two more widely available indicators (tax revenue and total spending). However, before using the aggregate indicator to achieve greater data coverage, one should be sure the different elements belong together. ${ }^{57}$

53. Beck, Katz, and Tucker 1998.

54. See, for example, Przeworski et al. 2000; and Smith 2004.

55. Specifically, the age of a political regime was coded as the lagged value of the DURABLE variable in Polity IV, which means that it is the number of years since there was a change of at least three in the Polity score.

56. In response to a reviewer's suggestion, I also ran the disaggregated analyses in Tables 3, 5, and 6 with an explicit measure of per capita borrowing instead of the residual category. The results did not change significantly.

57. Ideally, good instruments would exist for all these variables. However, I believe my operationalization lessens the possible concern about endogeneity driving the results. The dependent variable is a regime transition (or lack thereof) in year $t$, while all of the nontax variables are in $t-1$. Strictly speaking, it is therefore not possible that the dependent variable is causing the independent variable of consequence. In addition, though the underlying level of stability in time $t-1$ could be both correlated with stability in time $t$ and a cause of, for example, aid flows in time $t-1$, there are two variables in my regressions that account for exactly this underlying level of stability in time $t-1$. The first is the age of the regime (and its cubic splines), and the second is the number of regime transitions a country has experienced. While of course these two variables do not perfectly account for the level of regime stability in a country in the period before time $t$, they likely account for much of its variation across countries and time, and to the extent that that stability is correlated with nontax revenue, the inclusion of these variables would make it more difficult for me to observe significant coefficients on the nontax revenue variables. It is also possible that expectations about regime stability-rather than the past level of stabilitymight be doing some work, but it is quite likely that these expectations would be driven in large part by past experience in the country, such as that accounted for by the variables I have just discussed. 
TABLE 3. Nontax revenue's effect on regime instability

\begin{tabular}{|c|c|c|c|}
\hline Independent variable & Model 1 & Model 2 & Model 3 \\
\hline NONTAX REV. PER CAPITA $t-1$ & & $\begin{array}{l}-0.0007 * * * \\
(0.0002)\end{array}$ & $\begin{array}{c}-0.0009^{* * * *} \\
(0.0002)\end{array}$ \\
\hline GDP PER CAPITA GROWTH & $\begin{array}{c}-0.0534 * \\
(0.0319)\end{array}$ & $\begin{array}{l}-0.0565 * * * \\
(0.0200)\end{array}$ & $\begin{array}{l}-0.0552^{* * * *} \\
(0.0181)\end{array}$ \\
\hline GDP PER CAPITA $(l n)_{\cdot t-1}$ & $\begin{array}{c}0.0497 \\
(0.1584)\end{array}$ & $\begin{array}{c}-0.1922 * \\
(0.1059)\end{array}$ & $\begin{array}{l}0.0391 \\
(0.1226)\end{array}$ \\
\hline$\Delta \%$ POPULATION URBAN & $\begin{array}{l}0.3557 \\
(0.3638)\end{array}$ & $\begin{array}{l}0.5699 * * \\
(0.2491)\end{array}$ & $\begin{array}{c}0.2014 \\
(0.2334)\end{array}$ \\
\hline ETHNOLINGUISTIC FRACTIONALIZATION & $\begin{array}{c}0.3161 \\
(0.6058)\end{array}$ & $\begin{array}{c}-0.0315 \\
(0.5412)\end{array}$ & $\begin{array}{c}0.0710 \\
(0.5294)\end{array}$ \\
\hline POPULATION DENSITY $(\ln )_{t-1}$ & $\begin{array}{r}-0.0632 \\
(0.1211)\end{array}$ & $\begin{array}{c}-0.0161 \\
(0.0894)\end{array}$ & $\begin{array}{c}0.0344 \\
(0.0832)\end{array}$ \\
\hline PAST REGIME INSTABILITY & $\begin{array}{l}0.0888 \\
(0.0579)\end{array}$ & $\begin{array}{r}-0.0109 \\
(0.0559)\end{array}$ & $\begin{array}{l}0.0193 \\
(0.0548)\end{array}$ \\
\hline GRANTS PER CAPITA $_{t-1}$ & $\begin{array}{l}-0.0175^{* *} \\
(0.0076)\end{array}$ & & \\
\hline SOE REV. PER CAPITA $t_{t-1}$ & $\begin{array}{l}-0.0016^{* *} \\
(0.0006)\end{array}$ & & \\
\hline OTHER NONTAX REV. PER CAPITA $A_{t-1}$ & $\begin{array}{l}-0.0012 * * \\
(0.0006)\end{array}$ & & \\
\hline $\operatorname{POLITY}_{t-1}$ & & & $\begin{array}{l}-0.0700 * * * \\
(0.0229)\end{array}$ \\
\hline POLITY $_{t-1} *$ NONTAX REV. PER CAPITA $t-1$ & & & $\begin{array}{l}-0.0001 * * * \\
(0.0000)\end{array}$ \\
\hline REGIME AGE & $\begin{array}{c}-0.3470 * * * \\
(0.0753)\end{array}$ & $\begin{array}{c}-0.3704 * * * \\
(0.0562)\end{array}$ & $\begin{array}{l}-0.4067 * * * \\
(0.0615)\end{array}$ \\
\hline Spline (1) & $\begin{array}{l}0.0013^{* * *} \\
(0.0003)\end{array}$ & $\begin{array}{l}0.0013 * * * \\
(0.0002)\end{array}$ & $\begin{array}{l}0.0014 * * * \\
(0.0002)\end{array}$ \\
\hline Spline (2) & $\begin{array}{l}-0.0001 * * \\
(0.0000)\end{array}$ & $\begin{array}{l}-0.0001 * * * \\
(0.0000)\end{array}$ & $\begin{array}{l}-0.0001 * * * \\
(0.0000)\end{array}$ \\
\hline Constant & $\begin{array}{r}-1.576 \\
(1.203)\end{array}$ & $\begin{array}{l}0.4205 \\
(0.9691)\end{array}$ & $\begin{array}{c}-1.253 \\
(1.084)\end{array}$ \\
\hline Observations & 1307 & 1808 & 1808 \\
\hline Countries & 98 & 104 & 104 \\
\hline Probability $>\chi^{2}$ & 0.0000 & 0.0000 & 0.0000 \\
\hline Pseudo R-squared & 0.19 & 0.18 & 0.21 \\
\hline$A I C$ & 425.97 & 667.00 & 647.85 \\
\hline Area under ROC curve & 0.827 & 0.810 & 0.833 \\
\hline \% correctly classified & 95.3 & 94.4 & 94.3 \\
\hline
\end{tabular}

Notes: Dependent variable $=1$, if regime changes in current year; 0 otherwise. SOE REv. $=$ state-owned enterprise revenue. Table entries are logistic regression estimates with standard errors (in parenthesis) clustered by country. AIC $=$ Akaike information criterion. $* p \leq .10 ; * * \leq .05 ; * * * p \leq .01$.

As shown in Model 1 of Table 3, the coefficients on all three nontax revenue components are negative and significant (a negative coefficient indicates a stabilizing effect), and a linear combination of the three coefficients is also negative and significant (with a p-value of .008). This result is important in its own right, as it demonstrates that foreign aid, state-owned enterprise revenue, and other kinds of nontax 
revenue—including borrowing — have similar effects. While other scholars have suggested that foreign aid and oil revenues might have similar effects, this is the first systematic evidence to show that they do. In addition, the evidence indicates that even other kinds of nontax revenue, such as borrowing, have similar effects.

It is worthwhile to take a moment to discuss the results with regard to borrowing. On the one hand, the fact that borrowing has an effect similar to foreign aid and other nontax revenue may not be too surprising, as there is much evidence that loans to developing countries are often either forgiven or simply rolled over into new loans over the years. ${ }^{58}$ On the other hand, there certainly exist examples of countries that experience political instability due to financial crises brought on in part by extensive borrowing in previous years. This article offers a particular perspective on such instability: it is caused in part by an inability to access nontax revenue. The problem for the stability of regimes in the midst of, for example, a financial crisis is not, strictly speaking, that the government in power or its predecessors borrowed a lot of money in the past. The problem is that the government cannot borrow more now, because creditors have lost confidence that there is any hope for repayment. ${ }^{59}$ This inability to borrow more would be reflected in a decline in my measure of nontax revenue.

As I believe the results with the disaggregated nontax revenue variables provide support for aggregating nontax revenue, Model 2 of Table 3 reports the results with the aggregated nontax revenue variable. In the much larger sample, nontax revenue is negative and significant, indicating that nontax revenue reduces regime instability as predicted. Again, in addition to the evidence in Model 1, it might be noted here that it would be difficult to find a significant coefficient on this aggregated variable if its disaggregated components did not each work similarly. With respect to the other independent variables, there is evidence that economic growth is stabilizing to political regimes while urbanization is destabilizing, consistent with prior literature. There is weaker evidence that political regimes in more developed societies are more stable. ${ }^{60}$ The other variables do not reach standard levels of significance.

I submitted these results to a variety of robustness tests. First, I included a dummy variable in the regression that indicated whether the country belonged to the Organization for Economic Cooperation and Development (OECD), to be sure that the dynamics observed were not driven by rich countries. ${ }^{61}$ Second, I included dummy variables marking the 1970s and 1980s to control for temporal effects. Third, to

58. See Birdsall, Claessens, and Diwan 2003; and Easterly 2002.

59. The result is a tradeoff for governments: a decision about when and how much to tap into credit markets, when tapping into them at the present moment may mean a lack of access in the future. This kind of tradeoff is also relevant to other kinds of nontax revenue. For example, extracting more of a nonrenewable resource today means less of it will be available in the future. Exploring how governments make these tradeoffs, and the possible implications for regime stability, is an interesting avenue for future work.

60. The reason for the weakness of this evidence is probably that the level of development works differently in democracies and dictatorships, as discussed later in the text with regard to Table 7.

61. I also ran the regression on a sample only of developing countries, with similar results. 
control for regional effects, I included dummy variables representing the different regions of the world. None of these additions had any impact on the important results. ${ }^{62}$ In addition, I tested whether the inclusion of the change in nontax revenue made a difference. The lagged value of nontax revenue remained negative and significant (with a p-value of .002), while the change variable was also negative and significant (with a p-value of .015).

I also explored whether the results were different for different types of regimes. Given that the existing literature on oil and aid has focused on transitions to democracy, one might expect the effect of nontax revenue to be much stronger in dictatorships. I therefore included an interaction term of a country's POLITY score and its level of nontax revenue. The results of this regression are included in Model 3 of Table 3. They indicate that nontax revenue has a stabilizing effect in both dictatorships and democracies. In fact, the effect is stronger for more democratic regimes. For a country with a POLITY score of -7 , a drop from the 90th percentile of nontax revenue to the 10th percentile of nontax revenue would increase the probability of a regime transition 132 percent. For a country with $\mathrm{a}+7$ in the POLITY ranking, the same drop would increase the probability of regime transition by 1171 percent. ${ }^{63}$

Finally, I repeated the regression in Model 2 of Table 3 using alternative codings of regime change. First, I used the coding of Przeworski and his co-authors, who define democracies as regimes with functioning elections. ${ }^{64}$ Specifically, a regime is coded as democratic if the chief executive is elected, the legislature is elected, there is more than one party, and incumbents lose elections. If all of these characteristics are not present, the regime is a dictatorship. There are therefore no

62. In response to a reviewer, I also ran a regression with both year and country fixed effects. Using country fixed effects on regime transition data is problematic, as many countries that never have had a regime transition simply drop out of the data set. For this reason, Beck and Katz 2001 argue that country fixed effects should never be used in this type of analysis. Nevertheless, with a sample 53 percent smaller than the original (846 observations versus 1,808), nontax revenue was correctly signed and significant, with a p-value of .083 (as is to be expected when using fixed effects; in order to get the regression to converge I had to exclude ethnic fragmentation, a variable that does not change much over time).

63. The change from the 90th percentile to the 10th is of course particularly dramatic. However, a less severe drop, from the 75th to the 50th percentile, also produces strong effects (an increase in the probability of transition of 30 percent for dictatorships and 125 percent for democracies). These simulations were generated by the useful STATA command prvalue, written by Long and Freese (2006). The effect of nontax revenue is negative and significant at all levels of the PoLITY score. At the suggestion of an anonymous reviewer, I also ran this regression including a dummy variable for "anocracies," coded as a regime between -5 and +5 on the Polity scale. These regimes are thought to be more unstable, and the concern was that they might account disproportionately for regime changes and confound the estimation of the effect of nontax revenue in democracies and dictatorships. The anocracy variable was significant and indicated increased instability in these regimes, but nontax revenue remained statistically significant and substantively important (simply excluding these anocracies from the regression yielded similar results). Specifically, in the regression with the anocracy dummy variable included, the change from the 90th percentile to the 10th percentile increased the probability of a transition in dictatorships by 103 percent, and the probability of a transition in democracies by 537 percent. In a regime coded as a zero on the Polity scale, the same drop increased the probability of a transition by 234 percent.

64. Przeworski et al. 2000. 
"in-between" regimes-either a regime is a democracy or a dictatorship. Nontax revenue in this regression was again negative and significant (with a p-value of .003). Second, I used the regime coding of Bueno de Mesquita and his colleagues, who focus on the size of the winning coalition in a political regime ${ }^{65}$ Using various indicators from the Polity data set, they create a 5-point scale to represent coalition size. I considered a regime change any shift on this 5-point scale, and with this binary dependent variable, the important aspects of my results were again unchanged.

\section{Exploring the Causal Mechanisms}

Having established a robust association between nontax revenue and regime stability, in this section I explore the causal mechanisms suggested by my approach. Again, the theoretical framework suggests that threats to democracies come from wealthy elites, whereas threats to dictatorships come from citizens. Therefore, having seen that nontax revenue is associated with regime stability, one should also be able to observe that nontax revenue is associated with (1) less taxation of wealthy elites in democracies and (2) greater spending on poorer citizens in dictatorships.

To address these hypotheses, it is important to determine which taxes fall on the wealthy and what types of spending benefit citizens. Following Timmons, I use for my indicator of TAXATION OF ELITES a measure of revenue from taxation of "income, profits, and capital gains," a tax that falls heaviest on the rich. ${ }^{66}$ Similarly, I use SOCIAL SPENDING as an indicator of spending that benefits poorer citizens. ${ }^{67}$ While the benefits of social spending often are hard to pinpoint, it is reasonable to use such spending to approximate more progressive government action. As Timmons reviews, "empirical data from the United States and elsewhere ... show that lower-income groups systematically prefer more government involvement in healthcare, social welfare, industry, and the economy. Upperincome individuals, by contrast, do not need —and may not even want-government to provide basic public services." ${ }^{68}$ As with nontax revenue in the regime change regressions, both of these variables are standardized by population. They are calculated using the IMF's GFS data on revenue and spending, as well as data from the World Bank's World Development Indicators on population.

The statistical estimations are based on the fixed-effects error-correction model that has become standard in recent research on government finance. ${ }^{69}$ The equation estimated is as follows:

65. Bueno de Mesquita et al. 2003.

66. Timmons 2005.

67. Specifically, SOCIAL SPENDING is spending on health, education, housing, and welfare.

68. Timmons 2005, 541.

69. See, for example, Iversen and Cusack 2000; Kaufman and Segura-Ubiergo 2001; Rodden 2003; and Wibbels 2006. Also see Beck 2001. 


$$
\Delta \mathrm{Y}_{i, t}=\beta_{0}+\mathrm{Y}_{i, t-1} \beta_{1}+\mathrm{X}_{i, t-1} \beta_{2}+\Delta \mathrm{X}_{i, t} \beta_{3}+\varepsilon_{i, t}
$$

in which $\mathrm{Y}_{i, t}$ is the revenue or spending variable in country $i$ in time $t, \mathrm{X}$ is a matrix of independent variables (including country fixed effects), and $\Delta$ is the first difference operator. Therefore the dependent variable is the change in income tax revenue or social spending per capita from one year to the next. Table 4 gives the descriptive statistics of these variables for the main regressions below.

TABLE 4. Descriptive statistics of the taxation and spending dependent variables

\begin{tabular}{|c|c|c|c|c|c|}
\hline Variable & & Mean & $\begin{array}{l}\text { Standard } \\
\text { deviation }\end{array}$ & Minimum & Maximum \\
\hline \multirow[t]{3}{*}{ Change in income tax per capita } & Overall & 37.1 & 151.0 & -824.8 & 789.6 \\
\hline & Between & & 37.4 & -19.4 & 177.0 \\
\hline & Within & & 145.4 & -784.6 & 753.8 \\
\hline \multirow[t]{3}{*}{ Change in social spending per capita } & Overall & 1.18 & 93.1 & -1017.6 & 464.8 \\
\hline & Between & & 24.7 & -104.8 & 114.0 \\
\hline & Within & & 89.3 & -911.6 & 570.9 \\
\hline
\end{tabular}

Notes: These statistics refer to the dependent variables in the regressions in Model 2 of Tables 5 and 6.

As other authors have discussed, this type of model assumes a moving equilibrium relationship between variables, and it allows the estimation of both permanent and transitory relationships. ${ }^{70}$ The coefficient on the lagged level of the dependent variable $\left(\beta_{1}\right)$ is an indicator of equilibrium properties - that is, it should be between -1 and 0 , so that the effects of shocks in an exogenous variable are reduced over time and the system returns to equilibrium. The parameter of the lagged level of an independent variable $\left(\beta_{2}\right)$ indicates the permanent effect of a one-off change in that variable, while the parameter of the change variable $\left(\beta_{3}\right)$ is a measure of the transitory effect of that one-off change. In general, as has been noted elsewhere, the coefficient of interest is on the lagged value, which indicates the lasting effect of the variable in the long-term moving equilibrium. ${ }^{71}$ As is standard in the literature, the equation was initially estimated using ordinary least squares (OLS) with panel-corrected standard errors with panel-specific patterns of first-order autocorrelation, to accommodate the problems that plague cross-sectional time-series research designs, notably heteroskedasticity and serial correlation. ${ }^{72}$

70. For example, Beck 1991.

71. See Remmer 2004; and Rodden 2003.

72. Beck and Katz 1995. 
Again, the principal variable of interest is the nontax revenue variable defined above (NONTAX REVENUE PER CAPITA). Since my objective is to estimate the impact of nontax revenue on taxation and spending, I must also control for other factors that might affect government finance. Based on previous studies, I include four other control variables. Perhaps the most important is GDP PER CAPITA, to account for the effect of economic development on the size of the public sector. ${ }^{73}$ With only this variable and the nontax variable as independent variables in the errorcorrection regression described above, the coefficient on lagged nontax revenue is correctly signed and significant for both income tax in democracies ( $p$-value of .030) and social spending in dictatorships ( $p$-value of .001). Adding other control variables does not significantly alter the results. These variables include the percentage of the population that is 65 years and older (\% POPULATION OVER 65 ), since this tends to drive pensions and thereby social spending ${ }^{74}$; and trade dependence, measured as exports plus imports as a percentage of GDP (TRADE/ GDP), building off work that asserts a relationship between trade openness and the size of the public sector. ${ }^{75}$ In addition, in the regressions with taxation as the dependent variable, I include total government spending per capita (TOTAL EXPENDITURES PER CAPITA) as an independent variable, to isolate the effect of nontax revenue from increases or decreases in taxation simply due to changes in spending needs. ${ }^{76}$ Similarly, in the spending regressions, I include TOTAL TAX REVENUE PER CAPITA as a control. All of these variables are attained from the World Bank. ${ }^{77}$ Finally, as is standard in this research area, I include country dummies (fixed effects) in all of the regressions to avoid bias due to omitted variables that help determine long-term cross-country differences in government activity. ${ }^{78}$

Table 5 reports the results for the first set of estimations, which focus on democratic regimes. Following a convention established by prior research, the analysis is limited to countries scoring 7 or above on Polity IV's POLITY measure of political regimes (discussed above).$^{79}$ It may be noted, however, that the results of the statistical analysis are robust to changes in the POLITY threshold.

As with the regime change regressions, I first examined the results of a regression with the three disaggregated components of nontax revenue. As shown in Model 1, the lagged values of all three components are negative and significant, and the linear combination of the three coefficients is also negative and significant (with a p-value of .001), indicating again that combining the indicators into one variable is justified.

73. For example, Boix 2001.

74. For example, Perotti 1996.

75. For example, Rodrik 1998.

76. For example, Remmer 2004.

77. World Bank 2004.

78. See, for example, Beck 2001; Hsiao 2003; and Rodden 2003. I confirmed the need for fixed effects in the regressions using an F-test.

79. See, for example, Kadera, Crescenzi, and Shannon 2003; Reiter 2001; and Rousseau et al. 1996. 
TABLE 5. Nontax revenue's effect on taxation of elites in democracies

\begin{tabular}{|c|c|c|}
\hline Independent variable & Model 1 & Model 2 \\
\hline NONTAX REV. PER CAPITA $t_{t-1}$ & & $\begin{array}{c}-0.0466 * * \\
(0.0224)\end{array}$ \\
\hline GDP PER CAPITA $t_{t-1}$ & $\begin{array}{c}0.0000 \\
(0.0062)\end{array}$ & $\begin{array}{c}0.0041 \\
(0.0053)\end{array}$ \\
\hline$\%$ POPUlation OVER $65_{t-1}$ & $\begin{array}{c}16.39 * * \\
(6.755)\end{array}$ & $\begin{array}{c}9.802 \\
(6.080)\end{array}$ \\
\hline $\mathrm{TRADE} / \mathrm{GDP}_{t-1}$ & $\begin{array}{c}-0.0836 \\
(0.3551)\end{array}$ & $\begin{array}{c}0.2549 \\
(0.3542)\end{array}$ \\
\hline TOTAL EXPENDITURES PER CAPITA $t_{t-1}$ & $\begin{array}{c}0.0477 * * \\
(0.0197)\end{array}$ & $\begin{array}{c}0.0299 * \\
(0.0161)\end{array}$ \\
\hline GRANTS PER CAPITA $_{t-1}$ & $\begin{array}{c}-0.1336 * * * \\
(0.0472)\end{array}$ & \\
\hline SOE REV. PER CAPITA $t_{t-1}$ & $\begin{array}{c}-0.0895^{* *} \\
(0.0400)\end{array}$ & \\
\hline OTHER NONTAX REV. PER CAPITA $t_{t-1}$ & $\begin{array}{c}-0.0700^{* * * *} \\
(0.0261)\end{array}$ & \\
\hline$\triangle$ NONTAX REV. PER CAPITA & & $\begin{array}{c}-0.4352 * * * \\
(0.0252)\end{array}$ \\
\hline$\Delta$ GDP PER CAPITA & $\begin{array}{c}-0.0108 \\
(0.0141)\end{array}$ & $\begin{array}{c}-0.0096 \\
(0.0123)\end{array}$ \\
\hline$\Delta \%$ POPULATION OVER 65 & $\begin{array}{c}45.53 \\
(35.69)\end{array}$ & $\begin{array}{l}80.13 * * \\
(34.30)\end{array}$ \\
\hline$\Delta$ TRADE/GDP & $\begin{array}{c}0.6058 \\
(0.3950)\end{array}$ & $\begin{array}{c}0.7408 * * \\
(0.3687)\end{array}$ \\
\hline$\Delta$ TOTAL EXPENDITURES PER CAPITA & $\begin{array}{l}0.3396^{* * *} \\
(0.0276)\end{array}$ & $\begin{array}{l}0.3429 * * * \\
(0.0273)\end{array}$ \\
\hline$\Delta$ GRANTS PER CAPITA & $\begin{array}{c}-0.3016^{* * * *} \\
(0.0791)\end{array}$ & \\
\hline$\Delta$ SOE REV. PER CAPITA & $\begin{array}{c}-0.5439 * * * \\
(0.0607)\end{array}$ & \\
\hline$\triangle$ OTHER NONTAX REV. PER CAPITA & $\begin{array}{c}-0.4296 * * * \\
(0.0270)\end{array}$ & \\
\hline INCOME TAX REV. PER CAPITA $t_{t-1}$ & $\begin{array}{c}-0.1924 * * * \\
(0.0407)\end{array}$ & $\begin{array}{c}-0.1670^{* * *} * \\
(0.0345)\end{array}$ \\
\hline Constant & dropped & dropped \\
\hline Observations & 768 & 990 \\
\hline Countries & 60 & 66 \\
\hline$R$-squared & 0.56 & 0.58 \\
\hline Probability $>\chi^{2}$ & 0.0000 & 0.0000 \\
\hline
\end{tabular}

Notes: Dependent variable is change in per capita revenue from taxes on income, profits, or capital gains. SOE REV. = state-owned enterprise revenue. All regressions include fixed effects. Table entries are ordinary least squares (OLS) estimates corrected for panelspecific autocorrelation. Panel-corrected standard errors are in parenthesis. $* p \leq .10$; $* * p \leq .05 ; * * * p \leq .01$. 
Model 2 reports the results of the model with the aggregated nontax revenue indicator. The sample jumps from 769 to 991 observations, and aggregated nontax revenue is negative and significant. With respect to the other independent variables, the coefficients for both the change and lagged level of total expenditures are statistically significant and consistent with theoretical expectation. Similarly, the lagged level of income tax revenue is significant and negative, with a value between 0 and -1 as required for equilibrium in the error correction model. None of the other level variables are significant, though there is evidence of some shortterm effects of changes in the elderly population and openness to trade.

I subjected this model to a variety of robustness checks not reported here due to space constraints. The inclusion of an OECD dummy, decade dummies, and regional dummies had no effect on the main results. I also used different estimation techniques, as there is little consensus in the literature about the appropriate technique to use in this type of analysis. I first used generalized least squares with a panelspecific first-order autoregressive structure, and then used ordinary least squares with robust standard errors clustered by country. The important results were unchanged.

Finally, because income inequality plays an implicit role in the redistributional theoretical framework advanced above (in determining the demand for redistribution), I explored the effect of inequality in these regressions. Measures of inequality are of notoriously bad quality, and are only available for a subset of years and countries. For my measure of inequality, I used the Gini coefficient, employing the data of Dollar and Kraay ${ }^{80}$, who restrict their sample to income distribution measures based on nationally representative samples from the UN-WIDER World Income Database and the databases of Deininger and Squire, Lundberg and Squire, and Chen and Ravallion. ${ }^{81}$ Even if I follow Boix ${ }^{82}$ and use the five-year average of the Gini coefficient, to minimize volatility in the measure and maximize the number of observations, my sample drops considerably. To address this problem, I ran a reduced form model, only including the nontax revenue variable, GDP per capita, the measure of inequality, and the fixed effects. In this regression of 631 observations, inequality was positive but not significant (in both its change and lagged forms), while the nontax revenue variable remained negative and significant. In sum, all of these regressions provide evidence that nontax revenue leads to decreased taxation of elites in democracies.

I proceeded similarly with the regressions analyzing social spending in dictatorships (countries with a POLITY score equal to or below 6), reported in Table $6 .{ }^{83} \mathrm{I}$ first ran the regression with the three separate components of nontax revenue. As

80. Dollar and Kraay 2002.

81. See Chen and Ravallion 2000; Deininger and Squire 1996; Lundberg and Squire 2003; and United Nations World Institute for Development Economics Research (WIDER) 2000.

82. Boix 2001.

83. In all of my analyses, I excluded all observations in which Polity coded the country as -77 , which indicates a collapse of central state authority. 
TABLE 6. Nontax revenue's effect on social spending in dictatorships

\begin{tabular}{|c|c|c|}
\hline Independent variable & Model 1 & Model 2 \\
\hline NONTAX REV. PER CAPITA $A_{t-1}$ & & $\begin{array}{l}0.2095^{* * *} \\
(0.0418)\end{array}$ \\
\hline GDP PER CAPITA $t_{t-1}$ & $\begin{array}{c}-0.0063 \\
(0.0056)\end{array}$ & $\begin{array}{l}-0.0289 * * * \\
(0.0104)\end{array}$ \\
\hline$\%$ POPULATION OVER $65_{t-1}$ & $\begin{array}{l}0.4836 \\
(3.486)\end{array}$ & $\begin{array}{l}35.58^{* * * *} \\
(11.78)\end{array}$ \\
\hline $\mathrm{TRADE} / \mathrm{GDP}_{t-1}$ & $\begin{array}{c}-0.2922^{* * *} * \\
(0.0984)\end{array}$ & $\begin{array}{c}-0.3232 * \\
(0.1788)\end{array}$ \\
\hline TOTAL TAX REVENUE PER CAPITA $t-1$ & $\begin{array}{l}0.2260 * * * \\
(0.0472)\end{array}$ & $\begin{array}{l}0.2641 * * * \\
(0.0479)\end{array}$ \\
\hline GRANTS PER CAPITA $_{t-1}$ & $\begin{array}{l}0.2251^{* *} \\
(0.0916)\end{array}$ & \\
\hline SOE REV. PER CAPITA $t_{t-1}$ & $\begin{array}{c}0.0219 \\
(0.0274)\end{array}$ & \\
\hline OTHER NONTAX REV. PER CAPITA ${ }_{t-1}$ & $\begin{array}{c}0.0454^{*} \\
(0.0239)\end{array}$ & \\
\hline$\triangle$ NONTAX REV. PER CAPITA & & $\begin{array}{l}0.2412 * * * \\
(0.0460)\end{array}$ \\
\hline$\Delta$ GDP PER CAPITA & $\begin{array}{r}-0.0193 \\
(0.0151)\end{array}$ & $\begin{array}{l}0.0532 * * * \\
(0.0201)\end{array}$ \\
\hline$\Delta \%$ POPULATION OVER 65 & $\begin{array}{l}-9.889 \\
(27.50)\end{array}$ & $\begin{array}{l}182.2 * * \\
(71.73)\end{array}$ \\
\hline$\Delta$ TRADE/GDP & $\begin{array}{l}-0.2670^{* * *} \\
(0.1020)\end{array}$ & $\begin{array}{c}-0.3390^{*} \\
(0.2058)\end{array}$ \\
\hline$\Delta$ TOTAL TAX REVENUE PER CAPITA & $\begin{array}{l}0.4464 * * * \\
(0.0540)\end{array}$ & $\begin{array}{l}0.4135^{* * * *} \\
(0.0570)\end{array}$ \\
\hline$\Delta$ GRANTS PER CAPITA & $\begin{array}{l}0.5658^{* * * *} \\
(0.1006)\end{array}$ & \\
\hline$\Delta$ SOE REV. PER CAPITA & $\begin{array}{l}0.2574 * * * \\
(0.0309)\end{array}$ & \\
\hline$\triangle$ OTHER NONTAX REV. PER CAPITA & $\begin{array}{l}0.2251 * * * \\
(0.0241)\end{array}$ & \\
\hline SOCIAL SPENDING PER CAP. $t-1$ & $\begin{array}{l}-0.2354 * * * \\
(0.0890)\end{array}$ & $\begin{array}{l}-0.5545 * * * \\
(0.0823)\end{array}$ \\
\hline Constant & dropped & dropped \\
\hline Observations & 339 & 569 \\
\hline Countries & 45 & 55 \\
\hline$R$-squared & 0.78 & 0.82 \\
\hline Probability $>\chi^{2}$ & 0.0000 & 0.0000 \\
\hline
\end{tabular}

Notes: Dependent variable is change in per capita spending on health, education, welfare, and housing. SOE REV. = state-owned enterprise revenue. All regressions include fixed effects. Table entries are ordinary least squares (OLS) estimates corrected for panelspecific autocorrelation. Panel-corrected standard errors are in parenthesis. $* p \leq .10$; $* * p \leq .05 ; * * * p \leq .01$. 
shown in Model 1, all of the components had positive and significant coefficients except the indicator of state-owned enterprise revenue, which was positive but not significant. However, a Wald test could not reject the hypothesis that the coefficients on these variables were equal. In addition, the linear combination of the three coefficients is positive and significant (with a p-value of .006), again providing evidence that combining the indicators into one variable is justified.

Model 2 reports the results with the aggregated nontax revenue variable. In the larger sample, the coefficient on the lagged indicator is positive and significant, indicating support for the hypothesis that nontax revenue is associated with higher social spending in dictatorships. With regard to the other independent variables, the coefficients for both the change and lagged level of tax revenue are statistically significant and consistent with theoretical expectation. This is particularly important since the redistributional framework upon which my theory is based would assume this relationship holds. In addition, the lagged level of social spending is significant and negative, with a value between 0 and -1 as required for equilibrium in the error correction model. There is also evidence that dictatorships respond to older populations with increased social spending, and that more economically open dictatorships tend to spend less. Interestingly, richer dictatorships (that is, with higher GDP per capita) tend to spend less on social spending per capita than poorer dictatorships. Finally, there is also evidence that economic growth results in a short-term increase in social spending, as one would expect.

I submitted these results to the same robustness checks as the taxation regressions above. No substantive difference was observed with an OECD dummy variable, decade dummies, regional dummies, or different estimation techniques. I also ran a reduced form model with the inequality indicator, in which inequality was positive and significant (with a p-value on the lagged term of .003). The results for the nontax revenue variable were again unchanged.

These two sets of results-regarding elite taxation in democracies and social spending in dictatorships-provide support for my causal hypotheses linking nontax revenue to regime stability. However, these are not the only hypotheses that might link nontax revenue to regime stability, and it is important to consider alternatives. I will address here the three most evident alternative hypotheses related to government finance (my principal focus) and leave other hypotheses for future work. The alternative hypotheses within the arena of government finance are (1) nontax revenue's effect on some other form of taxation (besides taxation of elites) is at the center of the relationship between nontax revenue and democratic stability; (2) nontax revenue's effect on some other form of spending (besides social spending) is at the center of the relationship between nontax revenue and authoritarian stability; and (3) "booms" in nontax revenue are more important than levels of such revenue.

I assessed these alternative hypotheses by dividing my sample into dictatorships and democracies and running the regime change regression (from Model 2 of Table 3) with additional control variables. The results are reported 
in Table $7 .{ }^{84}$ For democracies, I included the additional control variable of all tax revenue other than that raised from taxes on income, profits, and capital gains (NONINCOME TAX REV. PER CAPITA). The goal was to isolate the causal mechanism of nontax revenue's effect on income tax and rule out the possibility that nontax revenue's effect was due to the reduction in other kinds of taxation. Nontax revenue remained significant and positive. For dictatorships, I included the additional control variable of all NONSOCIAL SPENDING PER CAPITA. This includes, for example, spending on the military and other spending on government projects such as infrastructure. The goal was to isolate nontax revenue's effect through social spending and rule out the possibility that nontax revenue's effect was due to spending in other areas. Again, nontax revenue remained significant. Finally, in both of these regressions, I included the change in nontax revenue per capita ( $\triangle$ NONTAX REV. PER CAPITA), to account for a "boom" effect. The boom effects were insignificant in both of the regressions.

In sum, while it is impossible to rule out other causal links between nontax revenue and regime stability, there is considerable support for the causal hypotheses advanced in this article. It is also interesting to note in passing some of the results of the control variables in these regressions. For example, the variable for all other tax revenue (besides income tax) has a destabilizing effect in democracies, contrary to what might be suggested by the literature on taxation leading to representation. In addition, the split samples reveal opposite effects of higher income per capita: a stabilizing effect in democracies and a destabilizing one in dictatorships, similar to what would be predicted by modernization theory. ${ }^{85}$ Economic growth is stabilizing in both, whereas urbanization and ethnolinguistic fractionalization only seem to be destabilizing to democracies.

\section{Conclusion}

This article has presented a theoretical framework for understanding why one should expect various kinds of nontax revenue to increase regime stability in both democracies and dictatorships. Based on theories of regime change that focus on redis-

tributional conflicts, I have argued that nontax revenue should not only stabilize

84. I am grateful to Tim Büthe for pointing out that the dependent variable in these regressions does not necessarily only pick up transitions from democracy to dictatorship, and vice versa. For example, a regime coded as a -4 in the Polity dataset would be considered a dictatorship. In the Polity coding, this dictatorship would experience a "regime change" if it moved to a -7 , but the new regime would be more authoritarian. A similar example would exist with democracies moving from 7 to 10 on the Polity scale. To ensure that these types of changes were not affecting my results, I split the sample into dictatorships and democracies and limited the dependent variable to positive changes for dictatorships and negative changes for democracies. That is, regime changes in these regressions were only counted if dictatorships moved three or more points in a democratic direction, or democracies moved three or more points in an authoritarian direction. The main results were unchanged.

85. For example, Epstein et al. 2006. 
130 International Organization

TABLE 7. Testing some additional hypotheses with regard to regime instability

\begin{tabular}{|c|c|c|}
\hline Independent variable & Democracies & Dictatorships \\
\hline NONTAX REV. PER CAPITA $t_{t-1}$ & $\begin{array}{c}-0.0021 * * \\
(0.0009)\end{array}$ & $\begin{array}{c}-0.0004 * * \\
(0.0002)\end{array}$ \\
\hline GDP GROWTH & $\begin{array}{c}-0.1446 * * * \\
(0.0527)\end{array}$ & $\begin{array}{c}-0.0541 * * \\
(0.0252)\end{array}$ \\
\hline GDP PER CAPITA $(l n)_{t-1}$ & $\begin{array}{c}-0.2422 \\
(0.3836)\end{array}$ & $\begin{array}{c}0.5689 * * \\
(0.2498)\end{array}$ \\
\hline$\Delta \%$ POPULATION URBAN & $\begin{array}{l}1.367^{*} \\
(0.7379)\end{array}$ & $\begin{array}{c}-0.2212 \\
(0.3686)\end{array}$ \\
\hline ETHNOLINGUISTIC FRACTIONALIZATION & $\begin{array}{l}3.955^{* * * *} \\
(1.502)\end{array}$ & $\begin{array}{r}-0.0287 \\
(0.7548)\end{array}$ \\
\hline POPULATION DENSITY $(l n)_{t-1}$ & $\begin{array}{c}0.1537 \\
(0.2955)\end{array}$ & $\begin{array}{c}-0.1202 \\
(0.1493)\end{array}$ \\
\hline PAST REGIME INSTABILITY & $\begin{array}{r}-0.3659 \\
(0.3396)\end{array}$ & $\begin{array}{c}0.0618 \\
(0.0916)\end{array}$ \\
\hline$\triangle$ NONTAX REV. PER CAPITA & $\begin{array}{c}-0.0006 \\
(0.0006)\end{array}$ & $\begin{array}{r}-0.0006 \\
(0.0004)\end{array}$ \\
\hline NONINCOME TAX REV. PER CAPITA $t_{t-1}$ & $\begin{array}{l}0.0006^{* *} * \\
(0.0003)\end{array}$ & \\
\hline NONSOCIAL SPENDING PER CAPITA $A_{t-1}$ & & $\begin{array}{r}-0.0004 \\
(0.0004)\end{array}$ \\
\hline REGIME AGE & $\begin{array}{c}-0.2472 \\
(0.2676)\end{array}$ & $\begin{array}{l}0.4112^{* * *} \\
(0.0728)\end{array}$ \\
\hline Spline (1) & $\begin{array}{c}0.0005 \\
(0.0010)\end{array}$ & $\begin{array}{l}0.0017^{* * *} * \\
(0.0004)\end{array}$ \\
\hline Spline (2) & $\begin{array}{c}0.0000 \\
(0.0001)\end{array}$ & $\begin{array}{c}-0.0002^{*} \\
(0.0001)\end{array}$ \\
\hline Constant & $\begin{array}{c}-3.242 \\
(3.034)\end{array}$ & $\begin{array}{c}-4.070 * * \\
(1.874)\end{array}$ \\
\hline Observations & 860 & 627 \\
\hline Countries & 57 & 57 \\
\hline Probability $>\chi^{2}$ & 0.0000 & 0.0000 \\
\hline Pseudo R-squared & 0.25 & 0.16 \\
\hline$A I C$ & 72.17 & 366.83 \\
\hline Area under ROC curve & 0.881 & 0.768 \\
\hline$\%$ correctly classified & 99.42 & 90.43 \\
\hline
\end{tabular}

Notes: Dependent variable $=1$ if regime changes in current year; 0 otherwise. Table entries are logistic regression estimates with standard errors (in parenthesis) clustered by country. AIC $=$ Akaike information criterion. * $p \leq .10 ; * * p \leq .05$;

$* * * p \leq .01$.

regimes but stabilize them through particular causal mechanisms. I have tested these hypotheses on all countries and years for which data are available and found strong support for them. Nontax revenue is associated with less taxation of elites in democracies and increased social spending in dictatorships, and more stability in both kinds of regimes.

In addition to the implications of its findings for the study of political regime stability, this article suggests some important new directions for the study of the 
political economy of government revenue. One of these implications concerns the aggregation and disaggregation of revenue types. As mentioned above, scholars studying nontax revenue have in general focused on disaggregated types of it: oil revenues, foreign aid, borrowing, and so forth. In contrast, political scientists studying tax revenue have generally ignored disaggregated types of it, such as taxes on the rich or poor, and focused instead on aggregate tax revenue. ${ }^{86}$ This latter approach has also generally been taken with regard to government spending, though an important exception is the study of social spending. This article offers evidence that leverage may be gained from taking new approaches to tax and nontax revenue, disaggregating the former while aggregating the latter. At the very least, propositions suggesting that certain types of nontax revenue act differently than others need to be defended, not assumed, as do propositions about aggregating tax revenue.

Another implication of this article for future research concerns current assumptions about the likely effects of revenue. As discussed in the introduction, existing research regarding different kinds of nontax revenue has tended to assume that certain kinds of revenue have what might be called "normative properties." That is, these various revenues have independent effects, pushing a country either toward dictatorship (in the case of oil for example) or toward democracy (in the case of aid). This article has taken a different approach, arguing that the effect of these revenues in terms of dictatorships and democracies is very much contextual: they stabilize the regime in which they appear. The results in Table 3 and Table 7-showing that nontax revenues are stabilizing in both dictatorships and democracies-provide support for this latter approach, and not the "normative" one.

From a policy perspective, this different approach has important consequences. For example, an approach that assumed foreign aid has democratic properties would imply that politicians interested in promoting democracy should favor giving aid to dictatorships. The findings of this article suggest precisely the opposite. While policymakers might be able to devise various modalities of aid that could avoid the stabilizing effects demonstrated in this article, it should be emphasized that most of the current modalities do not. ${ }^{87}$ The key aspect of nontax revenue in this theory is that it enables a dictatorship to spend money to satiate poorer citizens. Most aid works this way. Even with conditions attached, it is generally in the form of money that either goes directly to the government or bypasses the government and goes to projects that benefit poorer citizens. Conditionality attached to such aid has usually been ineffective, and far more focused on economic conditions than on political ones. ${ }^{88}$ One aid modality that may be exceptional is "technical assistance," which is often provided by donors in the form of people (that is,

86. Though see Timmons 2005 .

87. For example, Morrison 2007.

88. For example, Collier 1997. 
experts), not money ${ }^{89}$ However, this kind of aid makes up a clear minority of global aid flows.

The fact that aid seems to stabilize dictatorships might not be particularly concerning if global aid tended to flow to democracies. However, despite the end of the Cold War, this is not the case. In the latest year for which data are available (2006), almost two-thirds (64 percent) of net overseas development assistance from all donors went to countries not considered fully democratic by Freedom House. The United States was indicative of this trend, as 67 percent of U.S. aid that year went to countries not considered fully democratic. ${ }^{90}$ In other words, the majority of the world's foreign aid continues to go to-and stabilize-countries not fully democratic.

The policy implications of the approach of this article are also apparent with regard to oil. As an example, consider Mexico, a new democracy whose oil deposits are rapidly decreasing. ${ }^{91}$ The traditional perspective-arguing that oil rents hinder democratization - would predict that the decline in oil revenues would have a positive effect on Mexico's political regime. The perspective offered by this article would call for more caution. As Mexico's oil revenues continue to decline, there is likely to be increased pressure from citizens to redistribute resources from Mexico's elite. If history is a guide, the implications may not be positive for the future of Mexican democracy.

While these policy examples of aid and oil are important in their own right, one of the central findings of this article is the interchangeability of these and other resources. The implications of shifts in the availability of oil or aid revenues for political stability in developing regions of the world therefore need to be assessed in relationship to broader patterns of international financial flows. According to the World Bank, for example, the last several years have seen a massive decline in net official lending to developing countries. ${ }^{92}$ Given the documented impact of nontax revenue, one might anticipate rising instability and conflict in the developing world; however, this article emphasizes the importance of focusing on all nontax revenue. The World Bank explains in the same report that the decline in official lending has been driven by high oil prices, which have allowed major oil-exporting countries (such as Algeria, Nigeria, and Russia) to rapidly repay their debt and alleviated the need for further official borrowing. This broader perspective would indicate that nontax revenue has not declined, and that therefore regimes in the developing world are not necessarily becoming less stable.

89. See Collier 2006; and Gibson and Hoffman 2007.

90. These are my calculations, based on OECD data on foreign aid and Freedom House's coding of countries as "not free," "partially free," or "free" (at the time of writing, Polity data does not yet exist for 2006). Countries "not considered fully democratic by Freedom House" include those countries considered "not free" or only "partially free" by Freedom House. Excluding Iraq (coded as "not free" by Freedom House), the figures are 59 percent for all foreign aid and 60 percent for U.S. aid.

91. Wall Street Journal, 5 April 2007, A1.

92. World Bank 2007, 36 . 
In fact, there are indications that nontax revenue sources seem to be proliferating around the world, resulting in shifting patterns of international influence and regional stability. In Latin America, the obvious example is Venezuelan President Hugo Chavez, whose influence both within and outside the region revolves around the provision of nontax revenue to other countries. His proposal to form a regional "Bank of the South" (paid for and run by Latin American countries only) - as an alternative to the IMF, the World Bank, and the Inter-American Development Bank - can be seen in a similar light. In Asia, the desire to maintain exclusive control over large sources of nontax revenue was almost certainly behind the United States' vigorous resistance to the idea of an "Asian Monetary Fund" in the wake of the region's financial crisis in the late 1990s. ${ }^{93}$ In May 2007, finance ministers from thirteen Asian nations brought the main ideas of this fund to fruition, agreeing to pool part of their $\$ 2.7$ trillion of foreign-exchange reserves to prevent future economic crises. In Africa, where European countries and the United States have long dominated the purse strings, a major new player also has entered the nontax revenue game: China. In late 2006, China promised $\$ 5$ billion in soft loans and grants to African states over the following three years. That average of $\$ 1.67$ billion annually would have made China the fourth largest bilateral donor in Africa over the period of 2001-2005 (behind the United States, the United Kingdom, and France) ${ }^{94}$ Already western countries are complaining that China's influence will undermine their goals in the region, particularly with regard to democratization..$^{95}$ However, China is only one of several new sources of finance for African and other governments, as low-income countries have begun to access international debt markets in several ways. ${ }^{96}$

What is likely to be the effect on systemic stability of new and increasing sources of government finance, besides a likely decline in the influence of international financial institutions and the western donors that have dominated them? This article suggests that these new resources are likely to have a stabilizing effect on the world's regimes, as both democracies and dictatorships access increased nontax revenues. The implication would be a period of less regime transition, reducing a major source of political uncertainty and conflict in the developing world. ${ }^{97} \mathrm{~A}$ specific testing of this hypothesis is of course beyond the scope of this article, but it should be noted that much work on international finance and political regimes has explored whether financial flows are pro- or antidemocratic in general. ${ }^{98}$ This article indicates the possibility that, at least for flows to governments, this ques-

93. Lipscy 2003.

94. This comparison is made using data on overseas development assistance from the OECD 2007.

95. "Chinese Aid to Africa May Do More Harm Than Good, Warns Benn." The Guardian, 8 February 2007. Available at $\langle\mathrm{http} / / /$ www.guardian.co.uk/world/2007/feb/08/development.topstories3 . Accessed 14 October 2008.

96. World Bank 2007.

97. The flip side of this argument about nontax revenue is, of course, that falls in this revenue would lead to a period of greater instability.

98. For example, Rudra 2005. 
134 International Organization

tion might be poorly formulated. Like other nontax revenues, they may simply have stabilizing effects on whatever regime they enter.

These policy and research implications to one side, the arguments here will hopefully spur work toward a more complete theory of political regimes and revenue. It was more than eighty-five years ago that Schumpeter wrote, "the public finances are one of the best starting points for an investigation of society, especially though not exclusively of its political life." 99 In this tradition, scholars have produced major statements on the relationship between revenue and political regimes. ${ }^{100}$ However, these works-like the vast majority of work on the politics of taxation and spending-largely ignore the fact that much government revenue comes from nontax sources, many of which are more international than domestic in nature.

Now that scholars working on case studies of oil ${ }^{101}$ and aid ${ }^{102}$ have demonstrated how the availability of nontax revenue affects taxation and spending decisions, and as cross-national statistical studies of taxation and spending have explored the influence of oil, aid, and other nontax revenues, ${ }^{103}$ it is apparent that a revenue approach to political regimes that focuses only on taxation is incomplete. Such a significant portion of government revenues are derived from nontax sources that any research that deals with government finance, from theories of redistribution to theories of state-building, needs to take such revenues into account. The implications are clear for the important literature linking redistributional pressures to political regime change. Future theoretical and empirical work will need to account for the importance of nontax revenues and their stabilizing impact on political regimes.

\section{References}

Acemoglu, Daron, and James A. Robinson. 2001. A Theory of Political Transitions. American Economic Review 91 (4):938-63.

- 2006. Economic Origins of Dictatorship and Democracy. New York: Cambridge University Press.

Alesina, Alberto, Silvia Ardagna, Roberto Perotti, and Fabio Schiantarelli. 2002. Fiscal Policy, Profits, and Investment. American Economic Review 92 (3):571-89.

Anderson, Lisa. 1995. Peace and Democracy in the Middle East: The Constraints of Soft Budgets. Journal of International Affairs 49 (1):25-44.

Bates, Robert H., and Da-Hsiang Donald Lien. 1985. A Note on Taxation, Development, and Representative Government. Politics and Society 14 (1):53-70.

Beck, Nathaniel. 1991. Comparing Dynamic Specifications: The Case of Presidential Approval. Political Analysis 3 (1):51-87.

- 2001. Time-Series-Cross-Section Data: What Have We Learned in the Past Few Years? Annual Review of Political Science 4:271-93.

99. Schumpeter 1991, 101.

100. See for example, Brennan and Buchanan 1980; and Levi 1988.

101. For example, Chaudhry 1997.

102. For example, van de Walle 2001.

103. See, for example, Cheibub 1998; Remmer 2004; and Rodden 2003. 
Beck, Nathaniel, and Jonathan N. Katz. 1995. What to Do (and Not to Do) with Time-Series CrossSection Data. American Political Science Review 89 (3):634-47.

. 2001. Throwing Out the Baby with the Bath Water: A Comment on Green, Kim, and Yoon. International Organization 55 (2):487-95.

Beck, Nathaniel, Jonathan N. Katz, and Richard Tucker. 1998. Taking Time Seriously: Time-SeriesCross-Section Analysis with a Binary Dependent Variable. American Journal of Political Science 42 (4):1260-88.

Birdsall, Nancy, Stijn Claessens, and Ishac Diwan. 2003. Policy Selectivity Foregone: Debt and Donor Behavior in Africa. World Bank Economic Review 17 (3):409-35.

Boix, Carles. 2001. Democracy, Development, and the Public Sector. American Journal of Political Science 45 (1):1-17.

- 2003. Democracy and Redistribution. Cambridge: Cambridge University Press.

Bratton, Michael, and Nicolas van de Walle. 1997. Democratic Experiments in Africa: Regime Transitions in Comparative Perspective. Cambridge: Cambridge University Press.

Bräutigam, Deborah. 2000. Aid Dependence and Governance. Stockholm, Swden: Almqvist \& Wiksell International.

Brennan, Geoffrey, and James M. Buchanan. 1980. The Power to Tax: Analytical Foundations of a Fiscal Constitution. Cambridge: Cambridge University Press.

Bueno de Mesquita, Bruce, Alastair Smith, Randolph M. Siverson, and James D. Morrow. 2003. The Logic of Political Survival. Cambridge, Mass.: MIT Press.

Chaudhry, Kiren Aziz. 1997. The Price of Wealth: Economies and Institutions in the Middle East. Ithaca, N.Y.: Cornell University Press.

Cheibub, José Antonio. 1998. Political Regimes and the Extractive Capacity of Governments: Taxation in Democracies and Dictatorships. World Politics 50 (3):349-76.

Chen, Shaohua, and Martin Ravallion. 2000. How Did the World's Poorest Fare in the 1990s? Policy Research Working Paper 2409. Washington, D.C.: World Bank.

Collier, Paul. 1997. The Failure of Conditionality. In Perspectives on Aid and Development: ODC Essay No. 22, edited by Catherine Gwin and Joan M. Nelson, 52-78. Washington, D.C.: Overseas Development Council.

. 2006. Is Aid Oil? An Analysis of Whether Africa Can Absorb More Aid. World Development 34 (9):1482-97.

Deininger, Klaus, and Lyn Squire. 1996. A New Data Set Measuring Income Inequality. World Bank Economic Review 10(3):565-91.

Delacroix, Jacques. 1980. The Distributive State in the World System. Studies in Comparative International Development 15 (3):3-20.

Dollar, David R., and Aart Kraay. 2002. Growth Is Good for the Poor. Journal of Economic Growth 7 (3):195-225.

Dunning, Thad. 2004. Conditioning the Effects of Aid: Cold War Politics, Donor Credibility, and Democracy in Africa. International Organization 58 (2):409-23.

. 2008. Crude Democracy: Natural Resource Wealth and Political Regimes. Cambridge: Cambridge University Press.

Easterly, William. 2002. How Did the Heavily Indebted Poor Countries Become Heavily Indebted? Reviewing Two Decades of Debt Relief. World Development 30 (10):1677-96.

Epstein, David L., Robert Bates, Jack A. Goldstone, Ida Kristensen, and Sharyn O’Halloran. 2006. Democratic Transitions. American Journal of Political Science 50 (3):551-69.

Fearon, James D., and David D. Laitin. 2003. Ethnicity, Insurgency, and Civil War. American Political Science Review 97 (1):75-90.

Feyzioglu, Tarhan, Vinaya Swaroop, and Min Zhu. 1998. A Panel Data Analysis of the Fungibility of Foreign Aid. World Bank Economic Review 12 (1):29-58.

Gibson, Clark C., and Barak D. Hoffman. 2007. Can Foreign Aid Help Produce Democracy? A Political Concessions Model of Africa's Transition Period. Unpublished manuscript, University of California, San Diego. 
Goldberg, Ellis, Erik Wibbels, and Eric Mvukiyehe. 2008. Lessons from Strange Cases: Democracy, Development, and the Resource Curse in the U.S. States. Comparative Political Studies 41 (4-5):477-514.

Goldsmith, Arthur A. 2001. Foreign Aid and Statehood in Africa. International Organization 55 (1): $123-48$.

Herb, Michael. 2005. No Representation Without Taxation? Rents, Development, and Democracy. Comparative Politics 37 (3):297-317.

Herbst, Jeffrey. 2000. States and Power in Africa: Comparative Lessons in Authority and Control. Princeton, N.J.: Princeton University Press.

Horowitz, Donald L. 1985. Ethnic Groups in Conflict. Berkeley: University of California Press.

Hsiao, Cheng. 2003. Analysis of Panel Data. 2d ed. Cambridge: Cambridge University Press.

Huntington, Samuel P. 1968. Political Order in Changing Societies. New Haven, Conn.: Yale University Press.

- 1991. The Third Wave: Democratization in the Late 20th Century. Norman: University of Oklahoma Press.

International Monetary Fund (IMF). 1986. A Manual on Government Finance Statistics. Washington, D.C.:IMF.

- 2001. Government Finance Statistics Manual 2001. Washington, D.C.: IMF.

Ivanhoe, L. F. 2000. World Oil Supply-Production, Reserves, and EOR. Golden, Colo.: M. King Hubbert Center for Petroleum Supply Studies, Colorado School of Mines.

Iversen, Torben, and Thomas R. Cusack. 2000. The Causes of Welfare State Expansion: Deindustrialization or Globalization? World Politics 52 (3):313-49.

Jack, William, and Roger Lagunoff. 2006. Dynamic Enfranchisement. Journal of Public Economics 90 (4-5):551-72.

Jensen, Nathan, and Leonard Wantchekon. 2004. Resource Wealth and Political Regimes in Africa. Comparative Political Studies 37 (7):816-41.

Kadera, Kelly M., Mark J. C. Crescenzi, and Megan L. Shannon. 2003. Democratic Survival, Peace, and War in the International System. American Journal of Political Science 47 (2):234-47.

Karl, Terry Lynn. 1997. The Paradox of Plenty: Oil Booms and Petro-States. Berkeley: University of California Press.

Kaufman, Robert R., and Alex Segura-Ubiergo. 2001. Globalization, Domestic Politics, and Social Spending in Latin America: A Time-Series Cross-Section Analysis, 1973-1997. World Politics 53 (4):553-87.

Kitschelt, Herbert. 1992. Political Regime Change: Structure and Process-Driven Explanations? American Political Science Review 86 (4):1028-34.

Knack, Stephen. 2004. Does Foreign Aid Promote Democracy? International Studies Quarterly 48 (1):251-66.

Kousser, J. Morgan. 1974. The Shaping of Southern Politics: Suffrage Restriction and the Establishment of the One-Party South, 1880-1910. New Haven, Conn.: Yale University Press.

Landau, Daniel L. 1985. Government Expenditure and Economic Growth in the Developed Countries: 1952-76. Public Choice 47 (3):459-77.

Levi, Margaret. 1988. Of Rule and Revenue. Berkeley: University of California Press.

Lindert, Peter H. 2004. Growing Public: Social Spending and Economic Growth Since the Eighteenth Century. Cambridge: Cambridge University Press.

Lipscy, Phillip Y. 2003. Japan's Asian Monetary Fund Proposal. Stanford Journal of East Asian Affairs 3 (1):93-104.

Lipset, Seymour Martin. 1959. Some Social Requisites of Democracy: Economic Development and Political Legitimacy. American Political Science Review 53 (1):69-105.

Long, J. Scott, and Jeremy Freese. 2006. Regression Models for Categorical Dependent Variables Using Stata. 2d ed. College Station, Texas: Stata Press.

Lundberg, Mattias, and Lyn Squire. 2003. The Simultaneous Evolution of Growth and Inequality. Economic Journal 113 (487):326-44. 
Luong, Pauline Jones, and Erika Weinthal. 2006. Rethinking the Resource Curse: Ownership Structure, Institutional Capacity, and Domestic Constraints. Annual Review of Political Science 9:241-63.

Mahdavy, Hussein. 1970. The Patterns and Problems of Economic Development in Rentier States: The Case of Iran. In Studies in the Economic History of the Middle East: From the Rise of Islam to the Present Day, edited by M. A. Cook, 37-61. London: Oxford University Press.

Marshall, Monty G., and Keith Jaggers. 2003. Polity IV Project: Political Regime Characteristics and Regime Transitions, 1800-2002. Available at: 〈http://www.systemicpeace.org/polity/polity4.htm〉. Accessed 14 October 2008.

Meltzer, Allan H., and Scott F. Richard. 1981. A Rational Theory of the Size of Government. Journal of Political Economy 89 (5):914-27.

Moore, Barrington. 1966. Social Origins of Dictatorship and Democracy: Lord and Peasant in the Making of the Modern World. Boston: Beacon.

Moore, Clement Henry. 1976. Petroleum and Political Development in the Maghreb. In Arab Oil: Impact on the Arab Countries and Global Implications, edited by Naiem A. Sherbiny and Mark A. Tessler, 112-29. New York: Praeger.

Moore, Mick. 1998. Death without Taxes: Democracy, State Capacity, and Aid Dependence in the Fourth World. In The Democratic Developmental State: Politics and Institutional Design, edited by Mark Robinson and Gordon White, 84-121. Oxford, England: Oxford University Press.

Morrison, Kevin M. 2007. Natural Resources, Aid, and Democratization: A Best-Case Scenario. Public Choice 131 (3):365-86.

Musgrave, Richard A. 1959. The Theory of Public Finance. New York: McGraw-Hill.

North, Douglass C., and Barry R. Weingast. 1989. Constitutions and Commitment: The Evolution of Institutions Governing Public Choice in Seventeenth-Century England. Journal of Economic History 49 (4):803-32.

Organization for Economic Cooperation and Development (OECD). 2007. Development Co-Operation Report 2006: Efforts and Policies of the Members of the Development Assistance Committee. OECD Journal on Development 8 (1):1-238.

Perotti, Roberto. 1996. Growth, Income Distribution, and Democracy: What the Data Say. Journal of Economic Growth 1 (2):149-87.

Przeworski, Adam, Michael E. Alvarez, José Antonio Cheibub, and Fernando Limongi. 2000. Democracy and Development: Political Institutions and Well-Being in the World, 1950-1990. New York: Cambridge University Press.

Reiter, Dan. 2001. Does Peace Nurture Democracy? Journal of Politics 63 (3):935-48.

Remmer, Karen L. 1991. The Political Impact of Economic Crisis in Latin America in the 1980s. American Political Science Review 85 (3):777-800.

- 2004. Does Foreign Aid Promote the Expansion of Government? American Journal of Political Science 48 (1):77-92.

Rodden, Jonathan. 2003. Reviving Leviathan: Fiscal Federalism and the Growth of Government. International Organization 57 (4):695-729.

Rodrik, Dani. 1998. Why Do More Open Economies Have Bigger Governments? Journal of Political Economy 106 (5):997-1032.

Roeder, Philip G. 2001. Ethnolinguistic Fractionalization (ELF) Indices, 1961 and 1985. Available at 〈http://weber.ucsd.edu/ proeder/elf.htm〉. Accessed 14 October 2008. University of California, San Diego.

Ross, Michael L. 1999. The Political Economy of the Resource Curse. World Politics 51 (2):297-322.

—. 2001. Does Oil Hinder Democracy? World Politics 53 (3):325-61.

- 2004. Does Taxation Lead to Representation? British Journal of Political Science 34 (2):229-49.

Rousseau, David L., Christopher Gelpi, Dan Reiter, and Paul K. Huth. 1996. Assessing the Dyadic Nature of the Democratic Peace, 1918-88. American Political Science Review 90 (3):512-33.

Rudra, Nita. 2005. Globalization and the Strengthening of Democracy in the Developing World. American Journal of Political Science 49 (4):704-30. 
138 International Organization

Rueschemeyer, Dietrich, Evelyne Huber Stephens, and John D. Stephens. 1992. Capitalist Development and Democracy. Chicago: University of Chicago Press.

Schumpeter, Joseph A. 1991. The Crisis of the Tax State. In The Economics and Sociology of Capitalism, edited by Richard Swedberg, 99-140. Princeton, N.J.: Princeton University Press.

Shambayati, Hootan. 1994. The Rentier State, Interest Groups, and the Paradox of Autonomy: State and Business in Turkey and Iran. Comparative Politics 26 (3):307-31.

Smith, Alastair. 2008. The Perils of Unearned Income. Journal of Politics 70 (3):1-14.

Smith, Benjamin. 2004. Oil Wealth and Regime Survival in the Developing World, 1960-1999. American Journal of Political Science 48 (2):232-46.

Snyder, Richard, and Ravi Bhavnani. 2005. Diamonds, Blood, and Taxes: A Revenue-Centered Framework for Explaining Political Order. Journal of Conflict Resolution 49 (4):563-97.

Therborn, Göran. 1977. The Rule of Capital and the Rise of Democracy. New Left Review 103 (May-June):3-41.

Therkildsen, Ole. 2002. Keeping the State Accountable: Is Aid No Better Than Oil? IDS Bulletin 33 (3):41-50.

Tilly, Charles. 1990. Coercion, Capital, and European States, AD 990-1990. Cambridge, Mass.: Basil Blackwell.

Timmons, Jeffrey F. 2005. The Fiscal Contract: States, Taxes, and Public Services. World Politics 57 (4):530-67.

Ulfelder, Jay. 2007. Natural-Resource Wealth and the Survival of Autocracy. Comparative Political Studies 40 (8):995-1018.

United Nations World Institute for Development Economics Research (WIDER). 2000. World Income Inequality Database. Available at $\langle\mathrm{http}: / /$ www.wider.unu.edu/wiid/wiid.htm $\rangle$. Accessed 14 October 2008.

van de Walle, Nicolas. 2001. African Economies and the Politics of Permanent Crisis, 1979-1999. New York: Cambridge University Press.

Wibbels, Erik. 2006. Dependency Revisited: International Markets, Business Cycles, and Social Spending in the Developing World. International Organization 60 (2):433-68.

World Bank. 2004. World Development Indicators. CD-ROM. Washington, D.C.: World Bank.

. 2007. Global Development Finance 2007: The Globalization of Corporate Finance in Developing Countries. Washington, D.C.: World Bank. 